\section{Taxes, prices and illicit trade: the need for sound evidence}

\author{
Frank J Chaloupka
}

Extensive research from around the world has documented the effectiveness of tobacco tax and price increases in reducing tobacco use by promoting cessation among current users, deterring young people from taking up tobacco use, and reducing how much continuing users consume. Internal tobacco company documents show that the industry clearly understands this and that this knowledge informs its pricing, marketing, lobbying and other strategies. The collection of papers in this special issue addresses various aspects of how this plays out in practice and provides options for maximising the effectiveness of tax and price policies for achieving public health goals.

\section{DISTORTING THE DATA}

Exaggerating the role of tax and price levels and differentials for tobacco products in increasing illicit trade is a key element of the tobacco industry's playbook for discouraging governments from adopting higher taxes and, increasingly, for opposing other tobacco control policies, including strong graphic warning labels, plain packaging, bans on flavoured products, and other product standards. Several of the papers in this issue highlight how the industry distorts the data and misleads the public and policy makers on the issue of illicit tobacco trade. Rowell et $a l^{1}$ highlight how the industry has produced estimates of the extent of illicit trade in the UK to argue that the problem has increased over time and has been effective in getting this argument into the popular press, thus creating the incorrect impression that illicit trade in the UK is high and rising, while objective data show the opposite. Similarly, van Walbeek $^{2}$ uses revenue data to show that illicit tobacco trade in South Africa has not been consistently rising over time, contrary to industry claims that it had increased sharply and steadily since the 1990s, costing the government considerable revenues. Stoklosa and Ross $^{3}$ use alternative approaches to estimate the extent of illicit trade in Warsaw and

Correspondence to Professor Frank J Chaloupka, Department of Economics, University of Illinois at Chicago, Institute for Health Research and Policy, Chicago, IL 60608, USA; fj@uic.edu compare these estimates to industry estimates, likewise concluding that the industry significantly exaggerates the extent of the problem. Skafida et $a l^{4}$ conclude that this deception is even more of a problem in Bulgaria, where the industry not only makes exaggerated claims but has also been complicit in illicit trade, initially in efforts to gain access to Bulgaria's tobacco markets and more recently in attempts to deter tobacco tax increases. Gilmore et $a l^{5}$ provide a careful assessment of the estimates produced by KPMG in the Philip Morris International sponsored 'Project Star' that highlights a variety of problems that contribute to overestimates of the extent of illicit trade in many European Union countries, particularly Western European countries and countries where cross-border shopping is common. Finally, Gilmore and Reed ${ }^{6}$ document the inconsistency between the industry argument that tax and price increases will promote illicit trade and the industry's own price strategies, using data on changes in taxes and prices in the UK between 2006 and 2009. As they show, while taxes went up several times, retail price increases for most brands far exceed the tax increases, given significant industry price increases that account for about half of the retail price increase. They go on to note that if the industry was truly concerned about the impact of higher prices on illicit trade, they would be unlikely to push up prices to the extent that they did during this period. Together, these papers provide compelling evidence that the industry systematically overstates the extent of illicit tobacco trade and that estimates produced by the industry should not be considered by policymakers when assessing the extent of the problem in their countries and when considering how tax and price increases and/or strong tobacco control policies will influence illicit trade.

\section{MEASURING ILLICIT TRADE}

While the industry exaggerates the extent of the problem, other papers in this issue show that illicit tobacco trade is a significant concern in at least some jurisdictions, reducing government revenues and increasing tobacco use in these jurisdictions. Joossens et $\mathrm{al}^{7}$ use data collected in surveys of about 1000 adults in each of
18 European Union (EU) countries to develop a measure of illicit packs based on self-reported information on purchase location and price, as well as pack inspections focused on tax stamps and warning labels. They estimate relatively limited illicit trade penetration, with $<7 \%$ of packs likely illicit based on at least one of the four components of their measure. However, they do find considerable variability across countries, with little evidence of illicit packs in Portugal, Austria, Greece, Italy and Finland (all below 2\%), with more significant shares in Bulgaria (18.3\%), Sweden (18.8\%), and Latvia $(37.8 \%)$. Davis and colleagues, using estimates based on littered cigarette pack collections, conclude that illicit trade is a significant problem in four of the five cities in the north-eastern USA they examined. ${ }^{8}$ They find little evidence of illicit cigarettes in Philadelphia, while finding high levels of cigarette trafficking in Boston, New York, Providence, and Washington DC-up to $38.4 \%$, 49.9\%, $55.4 \%$, and $59.9 \%$, respectively.

\section{EFFECTIVE INTERVENTIONS}

Other papers in this special issue provide at least some rays of hope for effective interventions to combat illicit trade, while highlighting potential pitfalls. McNeill et $a l^{9}$ provide some encouraging evidence on the potential effectiveness of public education campaigns that raise awareness about the problems caused by illicit tobacco trade in their assessment of "The North of England Tackling Illicit Tobacco for Better Health Programme." This novel, social media-based programme featured two messages-one on the role of illicit tobacco in facilitating uptake among young people, and the other on how illicit trade brought crime to communities-and was effective in both raising awareness about the problem of illicit tobacco trade and in generating increased calls to telephone hotlines reporting tax evasion activities. While it's not possible to disentangle the programme's impact from other factors that contributed to the downward trend in illicit trade in the UK during this period, it does suggest that this type of public education campaign can be an important component of a comprehensive effort approach. Several papers discuss the potential role of the Illicit Trade Protocol to the WHO's Framework Convention on Tobacco Control, with some highlighting the central role of a global track-and-trace system. However, as Joossens and Gilmore ${ }^{7}$ note in their discussion of the Codentify system, all trace-and-trace systems are not created 
equally. In addition to highlighting several limitations of the Codentify system, Joossens and Gilmore stress the inherent conflict of adopting a system developed by a tobacco company, Philip Morris International, that has been found to be complicit in illicit trade, not to mention the conflict with Article 5.3 of the treaty which emphasises the need to protect tobacco control policies from the commercial and other interests of tobacco companies. Finally, in two papers, Blecher and colleagues describe the potential promise and peril of regional tobacco tax harmonisation agreements. ${ }^{10}{ }^{11}$ These papers provide some clear best and worst practices, drawing on the experiences of the EU, the Economic Community of West African States (ECOWAS), the West African Economic and Monetary Union (WAEMU), and the South African Customs Union (SACU). Regional tax harmonisation is one strategy for reducing the inter-jurisdictional price differences that contribute to some forms of tax avoidance and tax evasion, including the bootlegging that appears to be the source of most of the illicit trade in the US cities studied by Davis and colleagues. However, how this harmonisation is accomplished can have very different implications for tobacco control. In this respect, the approach to harmonisation used in the EU, which establishes a high floor for tobacco taxes in both absolute terms and as a percentage of retail prices, will have a much greater impact than an approach that sets a low ceiling on these taxes, as done in ECOWAS.
The final paper reminds us that tobacco company pricing strategies for licit tobacco products cannot be ignored. Burton et al ${ }^{12}$ document the extent of price-reducing marketing strategies in Australia, including multi-pack deals and price discounts, concluding that the prevalence of these promotions was greatest in stores in neighbourhoods with more price sensitive consumers-those with higher percentages of young people and with lower socioeconomic status.

The papers in this special issue show us that while considerable progress has been made around the world, the tobacco industry continues to adapt its arguments and strategies in efforts to mitigate the impact of tobacco tax and price increases and to deter governments from further tax increases. Continuing to document these activities while at the same time researching strategies to enhance the effectiveness of tax and price policies for tobacco control remains critical to providing the sound evidence that policymakers need to take effective action.

\section{Competing interests None.}

Provenance and peer review Commissioned; internally peer reviewed.

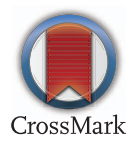

To cite Chaloupka FJ. Tob Control 2014;23:e1-e2.

Tob Control 2014;23:e1-e2. doi:10.1136/tobaccocontrol-2014-051739

\section{REFERENCES}

1 Rowell A, Evans-Reeves K, Gilmore AB. Tobacco industry manipulation of data on and press coverage of the illicit tobacco trade in the UK. Tob Control 2014;23:e35-43.

2 van Walbeek C. Measuring changes in the illicit cigarette market using government revenue data: the example of South Africa. Tob Control 2014;23: e69-74.

3 Stoklosa M, Ross H. Contrasting academic and tobacco industry estimates of illicit cigarette trade: evidence from Warsaw, Poland. Tob Control 2014;23:e30-4.

4 Skafida V, Silver KE, Rechel BPD, et al.Change in tobacco excise policy in Bulgaria: the role of tobacco industry lobbying and smuggling. Tob Control 2014;23:e75-84.

5 Gilmore AB, Rowell A, Gallus $S$, et al. Towards a greater understanding of the illicit tobacco trade in Europe: a review of the PMI funded 'Project Star' report. Tob Control 2014;23:e51-61.

6 Gilmore $A B$, Reed $H$. The truth about cigarette price increases in Britain. Tob Control 2014;23: e15-16.

7 Joossens L, Gilmore AB. The transnational tobacco companies' strategy to promote Codentify, their inadequate tracking and tracing standard. Tob Control 2014;23:e3-6.

8 Davis KC, Grimshaw V, Merriman D, et al. Cigarette trafficking in five northeastern US cities. Tob Control 2014;23:e62-8.

9 McNeill A, Iringe-Koko B, Bains $M$, et al. Countering the demand for, and supply of, illicit tobacco: an assessment of the 'North of England Tackling Illicit Tobacco for Better Health' Programme. Tob Control 2014;23:e44-50.

10 Blecher $E$, Drope J. The rewards, risks and challenges of regional tobacco tax harmonisation. Tob Control 2014;23:e7-11.

11 Blecher E, Ross H, Stoklosa M. Lessons learned from cigarette tax harmonisation in the European Union. Tob Control 2014;23:e12-14.

12 Burton S, Williams K, Fry R, et al. Marketing cigarettes when all else is unavailable: evidence of discounting in price-sensitive neighbourhoods. Tob Control 2014;23:e24-9. 